\title{
DEGLACIATION OF THE HIGH TATRA MOUNTAINS
}

\author{
M. MAKOS \\ Climate Geology Department, Faculty of Geology, University of Warsaw, Żwriki \\ i Wigury St. 93 02-089 Warsaw, Poland.
}

\begin{abstract}
Investigation on the glaciation of the High Tatra Mountains has an over 200 years long history. The chronology of the last deglaciation of the massif has been based mainly on geomorphologic evidence, thermo-luminiscence (TL) dating and few radiocarbon ages. This study presents the current state of knowledge about the last glacial cycle and its termination in the High Tatra Mountains based on exposure age chronology. ${ }^{36} \mathrm{Cl}$ dating of glacial features applied on both the northern and the southern slope of the range, indicates that the maximum advance (LGM I) occurred in the time range between 25 and 20 $k a$ and the subsequent episode (LGM II) when glaciers were stable, took place at around $18 \mathrm{ka}$. The mean annual temperature was depressed by $11-12^{\circ} \mathrm{C}$ in relation to the modern conditions and precipitation was 40-50\% of the present day value. The younger glacier advances or stillstands likely occurred at around 17-16 ka (LG1) and at $15 \mathrm{ka}$ (LG2). Both of them can be correlated with the Greenland Stadial 2 a (the Oldest Dryas). Modelled climatic conditions indicate cold and dry climate with $9-10^{\circ} \mathrm{C}$ lower temperature and 30-50\% lower precipitation. The Lateglacial Interstadial 2 is recorded as fast thinning of glaciers in the upper part of the catchments between 15 and $13 \mathrm{ka}$. The LG3 glacial episode is marked by well-fomed terminal moraines which were formed at around $12.5 \mathrm{ka}$. This cooling correlates well with the Younger Dryas (Greenland Stadial 1) when temperature in the Tatra Mountains was lower than today by about $6^{\circ} \mathrm{C}$ and precipitation was about $75 \%$ of current values.
\end{abstract}

\section{Deglaciación de la alta montaña del Tatra}

RESUMEN. La investigación sobre la glaciación de la alta montaña del Tatra tiene unos 200 años de antigüedad. La cronología de la última deglaciación del macizo se ha basado principalmente en evidencias geomorfológicas, datación por termoluminiscencia (TL) y unas pocas fechas de radiocarbono. Este estudio presenta el estado actual del conocimiento sobre el último ciclo glacial y su terminación en la alta montaña del Tatra a partir de una cronología de cosmogénicos. La datación con $\mathrm{Cl}^{36}$ de ciertos rasgos glaciares tanto en la vertiente septentrional como en la meridional de la cadena, indica que el máximo avance (LGM I) ocurrió entre 25 y 20 ka, y el subsiguiente episodio (LGM II), cuando los glaciares se estabilizaron, tuvo 
lugar alrededor de $18 \mathrm{ka}$. La temperatura media anual descendió en unos $11-12^{\circ} \mathrm{C}$ en relación con las condiciones actuales, y la precipitación fue el 40-50\% inferior a la actual. Otros avances o estabilizaciones más recientes ocurrieron alrededor de 17-16 ka (LG1) y de $15 \mathrm{ka}$ (LG2). Ambos pueden correlacionarse con el Greenland Stadial 2 a (Oldest Dryas). La modelización de las condiciones climáticas indican un clima frío y seco, con una temperatura inferior en unos $9-10^{\circ} \mathrm{C}$ y una precipitación inferior en un 30-50\%. El Interestadial 2 del Tardiglaciar se ha registrado como un rápido adelgazamiento de los glaciares en la cabecera de las cuencas entre 15 y $13 \mathrm{ka}$. El episodio glacial LG3 aparece marcado por morrenas terminales muy bien formadas alrededor de 12,5 ka. Este enfriamiento se correlaciona bien con el Younger Dryas (Greenland Stadial 1) cuando la temperatura en los Montes Tatra fue unos $6^{\circ} \mathrm{C}$ inferior a la actual, y la precipitación alcanzó un $75 \%$ de los valores actuales.

Key words: exposure age chronology, deglaciation, glacier-climate modeling, LGM, Lateglacial, High Tatra Mountains.

Palabras clave: Cosmogénicos, deglaciación, modelización glaciar-clima, LGM, Tardiglaciar, alta montaña del Tatra.

*Corresponding author: Climate Geology Department, Faculty of Geology, University of Warsaw, Żwriki i Wigury St. 93 02-089 Warsaw, Poland. E-mail: michalmakos@ uw.edu.pl

\section{Introduction}

Research on the Pleistocene glaciation of the Tatra Mountains has been carried out for over 200 years. During that time many of the researchers presented their conclusions about the number and age of glacial cycles and spatial and temporal distribution of glaciers. The Tatra Mountains, situated on the Polish-Slovakian border are 57 kilometres long and 25 kilometres wide (Fig. 1). The range is geographically divided into two parts: the lower Western Tatras and the higher Eastern Tatras (High Tatra Mountains). This reflects the geological composition of the massif, with metamorphic and sedimentary rocks on the west and plutonic rocks on the east. The Tatra Mountains are the highest massif of the Western Carpathians, reaching 2655 m a.s.l. (Gerlachovský Stit). Inferring from geomorphologic evidence and dating, the massif was glaciated at least several times. Additionally, it was the northernmost mountain range of the European alpine mountains with glaciers during the Pleistocene. The High Tatra Mountains are deeply incised by glacial valleys and cirques, but are not currently occupied by glaciers. Only small glacierets or perennial snowfields exist in the glacial cirques below steep rock walls exposed to the north (Gądek, 2008). These features are located clearly below the climatic snow line, which is located at 2500-2600 $\mathrm{m}$ a.s.l. on the northern side and at 2700-2800 m a.s.l. on the southern side (Zasadni and Kłapyta, 2009). 


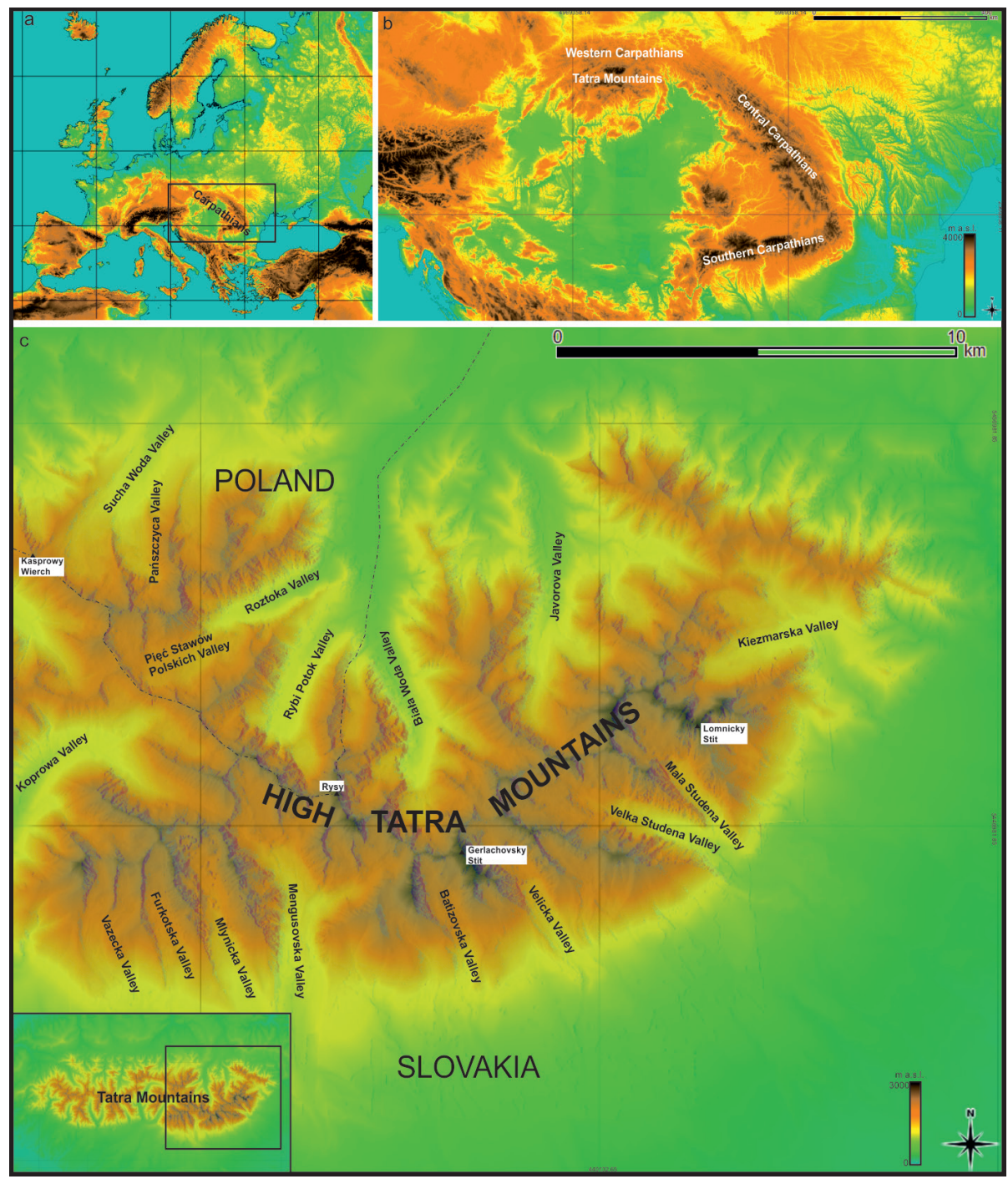

Figure 1. Location of the study area. a) Location of the Carpathians in Europe; b) Location of the Tatra Mountains in the Carpathians; c) Location of the High Tatra Mountains. Dasheddotted line is the boundary between Poland and Slovakia.

The High Tatra Mountains are located in the transitional climatic zone, under the influence of the polar-oceanic humid air masses. The data set from one of the two warmest periods of the 20th century (1990-2000) demonstrates that the distribution of mean annual temperature is nearly uniform on both sides (northern and southern) of the massif with only slightly higher values $\left(0.5^{\circ} \mathrm{C}\right)$ on the southern slope. Temperature ranges from 5 to $6^{\circ} \mathrm{C}$ inside the dales on the foreland of the Tatras to $-4^{\circ} \mathrm{C}$ on the highest peaks. Distribution of precipitation is more complicated. Annual precipitation at the 
same elevation is about $40 \%$ higher on the northern side than on the southern side. This is mostly due to the prevailing northwestern atmospheric circulation and direction of moisture transport in central Europe (Niedźwiedź, 1992).

The geomorphologic study on the glacial landforms were carried out by many researchers in both the Polish and the Slovakian Tatra Mountains (e.g. Lukniš, 1973; Klimaszewski, 1988). All glacial catchments have very well-developed systems of glacial accumulation and erosional features with e.g: terminal and lateral moraines, glacial trimlines, rocheés mountoneés, glacial polish, striae and fossil rock glaciers. Well-preserved moraine ridges were the primary basis for morphostratigraphic studies and reconstruction of deglaciation chronology in the study area (Lindner, 1994; Lindner et al., 2003; Baumgart-Kotarba and Kotarba, 1997; 2001; 2002) (Fig.2).

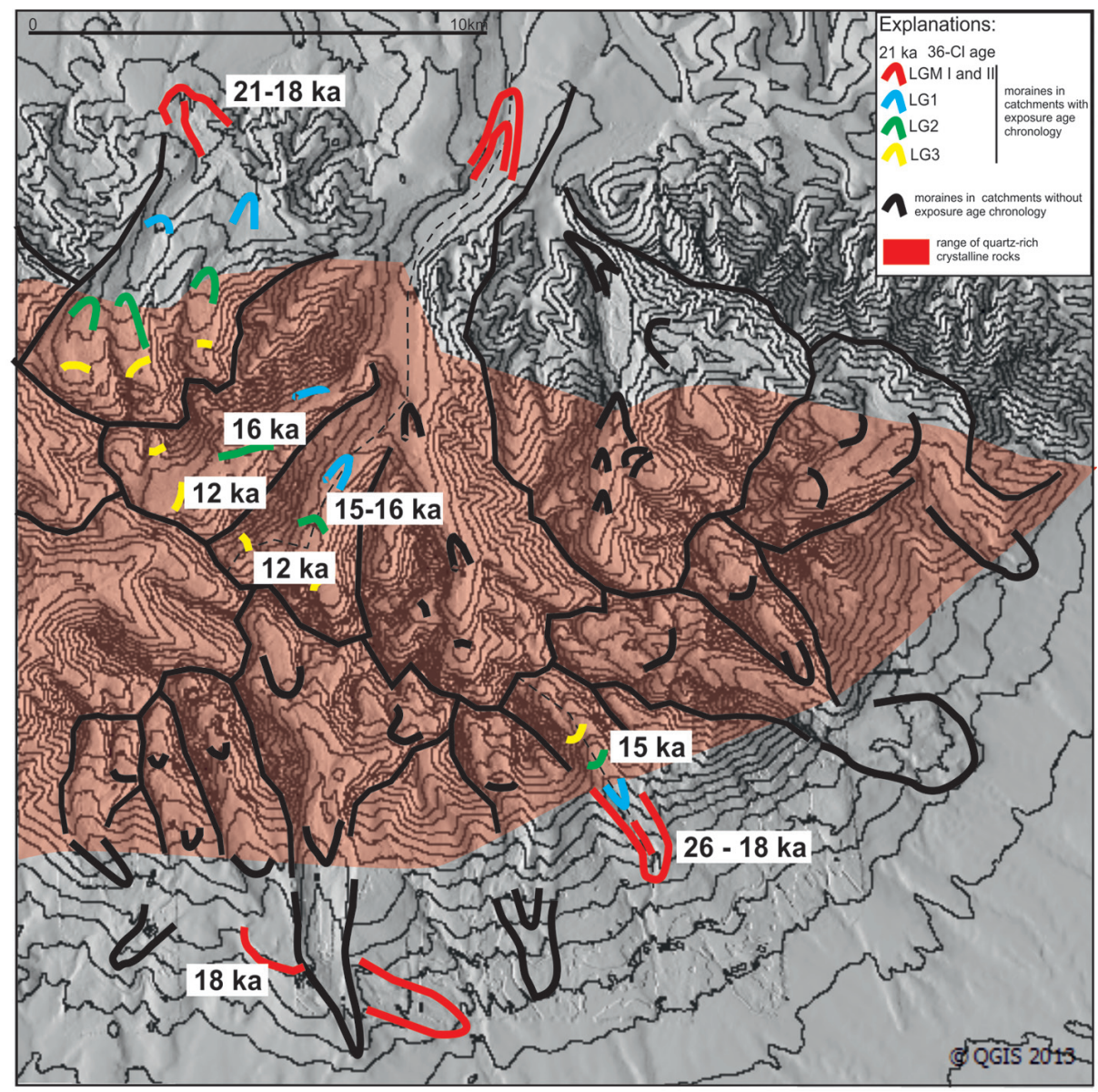

Figure 2. Distribution of moraine ridges in the study area. The position of the moraines in the Slovakian High Tatras based on Lukniš (1973). Coloured moraines marked in catchments with exposure age chronology. 
The aim of this paper is to present the current state of knowledge on the timing of deglaciation of the High Tatra Mountains based on exposure age chronology of glacial landforms and some of historical data sets. Moreover, the course of deglaciation is supported by paleoclimatological parameters as equilibrium line altitude of glaciers, mean summer and annual temperature and sum of annual precipitation which are reconstructed based on glacier-climate modeling (Makos and Nitychoruk, 2011; Makos et al., 2013 a and b; 2014).

\section{Glacial history of the Tatra Mountains}

The glacial history of the Tatra Mountains is primarily based on the geomorphologic evidence. During the long period of investigations focused on the Quaternary glaciations most geomorphologic and palaeogeographical studies were carried out in the High Tatras and therefore, local glacial landforms and their temporal assignment in this area are better understood, when compared to the Western Tatra Mountains. In the first half of the $20^{\text {th }}$ century, glaciations of the High Tatras were extensively studied mainly by Partsch (1923) who confidently recognized traces of two glaciers' advances. Further opinions about the course of the "ice age" were proposed by e.g. Vitásek (1931) and Romer (1929). Detailed case-studies from individual valleys have brought new light into separate morphostratigraphic situations of moraine remnants and associated glacial deposits, whereas work by Lukniš (1964) refers to the paleoclimatic conditions and geomorphological evolution of the range as a whole. The most comprehensive and detailed monograph concerning landforms of the High Tatras has been the one by Lukniš (1973), who has recognized three main Quaternary glaciations of the High Tatras, relating them to the traditional alpine nomenclature (Mindel- nowadays correlated with MIS 12; Riss - MIS 6-10; and Würm - MIS 5d-2) and determined that the penultimate glaciation was the most extensive. On the basis of the moraine morphostratigraphy, Lukniš (1973) defined within the Last Glacial (Würm) five cold stages corresponding to prominent glacier advances (stadials, marked by letters A-E) and one cold interval at the beginning of the Holocene (Fig. 3). Two older glacial periods (Mindel, Riss) are according to Lukniš (1973) represented only in the form of glaciofluvial deposits. Since the Lukniš's fundamental contribution, many different and contradictory opinions from both the Polish and the Slovak researchers have been voiced regarding the age and extension of glaciations in the High Tatras (e.g., Klimaszewski, 1988; Halouzka, 1992; Lindner et al., 2003; Halouzka and Horniš, 1995; Baumgart-Kotarba and Kotarba, 1997, 2001, 2002).

Analysis of glaciofluvial levels on the northern foreland of the massif allowed distinguishing eight glacial cycles (Lindner et al., 2003), timing of which was constrained with the use of thermo-luminiscence (TL) dating methodology (Lindner et al., 2003). Six older glacial events are represented only by glaciofluvial series. Two last glaciations (Riss and Würm) are evidenced by glaciofluvial and glacial deposits (Klimaszewski, 1988, BaumgartKotarba and Kotarba, 1997, Lindner et al., 2003). The extent of the Riss glaciation, however, is not well established due to the lack of well preserved moraine ridges. Würm glaciation is subdivided into three stadials (Suchej Wody, Bystrej, Białki). Glaciofluvial deposits of particular stadials gave TL ages of $89 \pm 13-81 \pm 12 \mathrm{ka}, 69 \pm 10-57 \pm 8 \mathrm{ka}$, and $32 \pm 5-25 \pm 4 \mathrm{ka}$, 
respectively (Butrym et al., 1990; Lindner, 1994). According to Lindner et al. (2003), the maximum extent of the Białka Stadial occurred during the Hurkotne phase. The following recessional phases (Łysa Polana, Włosienica I - III and Pięć Stawów Polskich I - IV) took place at $23 \pm 3,16 \pm 2$ and $14 \pm 2$ ka ago, respectively (Fig. 3). It has to be emphasized, however, that TL dating method has limited precision, thus thermoluminescence-based stratigraphy can be treated with very limited confidence. The very interesting deglaciation pattern of the High Tatra Mountains was presented by Baumgart-Kotarba and Kotarba (1997; 2001; 2002). The authors distinguished ten phases of deglaciation in the Biała Woda Valley and seven phases of deglaciation in the Rybi Potok Valley, Roztoka Valley, Pańszczyca Valley and SuchaWoda Valley (Fig. 3). All phases are represented by recessional moraines. They were correlated with Alpine stadials according to Patzelt (1975). These findings are partly confirmed by OSL and SAR dating of the maximum moraine in the Sucha Woda Valley (Baumgart-Kotarba and Kotarba, 2002) as well as by ${ }^{14} \mathrm{C}$ dating of lacustrine sediments in the Czarny Staw Gąsienicowy Lake (Baumgart-Kotarba and Kotarba, 2001). Dzierżek et al. (1999) applied the terrestrial in-situ nuclides (TCN) methodology in the Tatra Mountains for the first time ever. They measured the age of exposure of moraine boulders and glacial polish, using the cosmogenic isotope ${ }^{36} \mathrm{Cl}$. The obtained data set partly confirmed previous assumptions and was very promising for future analysis. For the next ten years, however, no other research has been performed using cosmogenic isotopes in the Tatra Mountains. Finally, Dzierżek (2009) presented the whole data set from Dzierżek et al. (1999) and a number of previously unpublished data, recalculated accordingly to the current knowledge of age calculation, correction analyses etc. Most of dates changed significantly, showing older ages. The new data set allowed to distinguish a few groups of ages from which the two oldest are 90-85 ka and 43-32 ka. The other groups of ages are clearly younger and represent time intervals: 26-23 ka, 22-20 ka, 18-16 ka and $14-10 \mathrm{ka}$. The recent ${ }^{36} \mathrm{Cl}$ dating of glacially abraded bedrock and moraines in the High Tatra Mountains made their deglaciation chronology more precise (Makos et al., 2013 a and b, 2014) (Figs. 3 and 4).

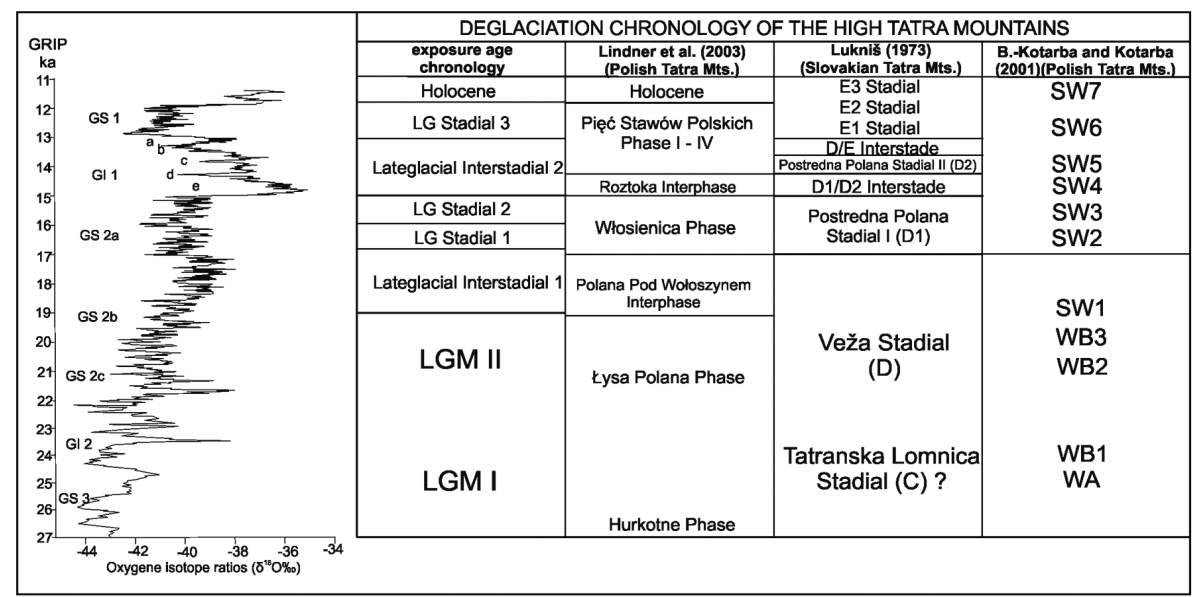

Figure 3. Different stratigraphic schemes for the LGM and the Lateglacial in the High Tatra Mountains related to the exposure age chronology based on the ${ }^{36} \mathrm{Cl}$ datings presented by Dzierziek (2009), Makos et al. (2013a and b; 2014). 


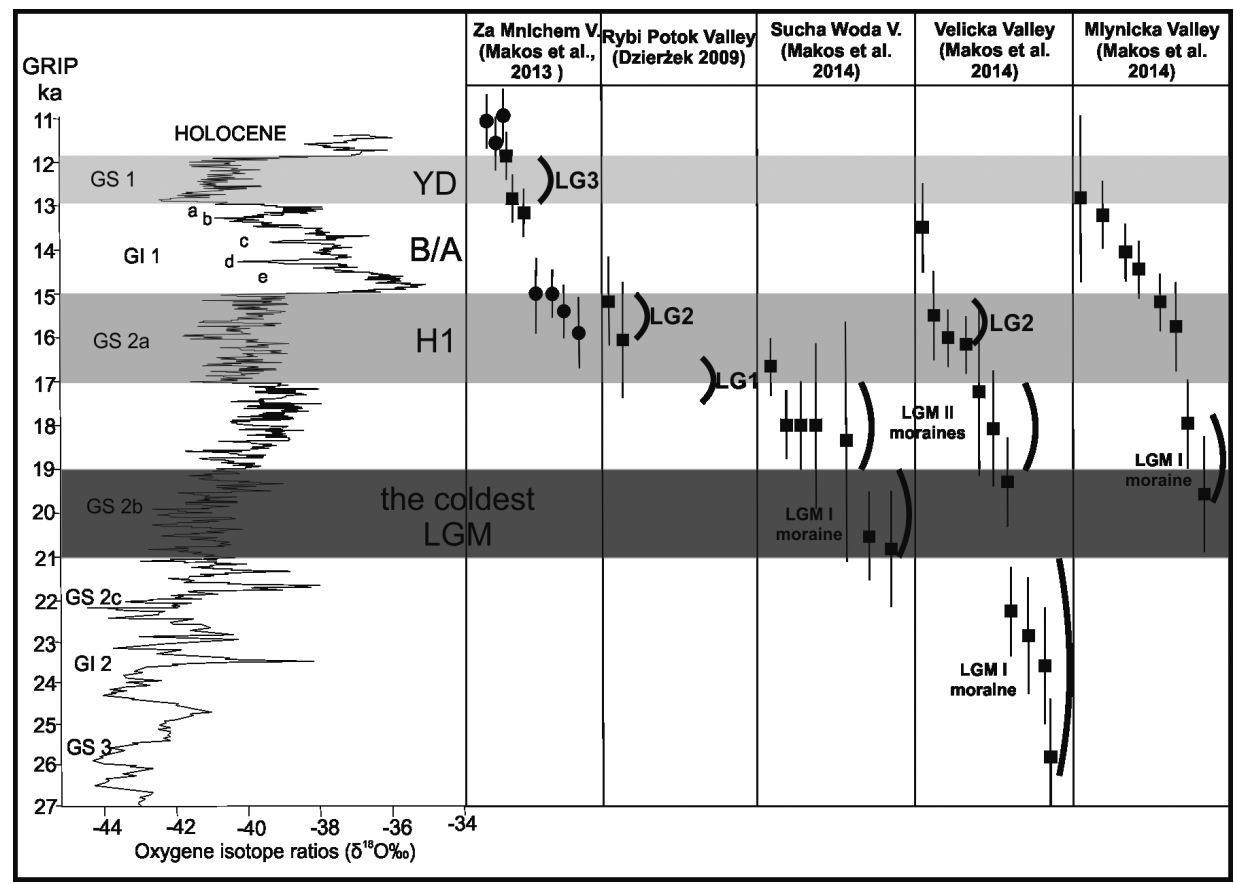

Figure 4. Plot of exposure ages for samples from the study area and other locations in the Tatra Mountains against the GRIP ice-core record (Lowe et al., 2008). Published time ranges of the

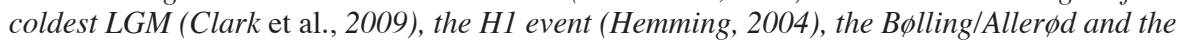
Younger Dryas (Rasmussen et al., 2006) are indicated. Squares show samples from the moraine boulders and circles those of samples from the bedrock surfaces below glacial trimlines.

\section{The Late Würm in the High Tatra Mountains}

\subsection{Last Glacial Maximum}

During the Last Glacial Maximum almost all catchments in the High Tatra Mountains were occupied with valley glaciers (Makos et al., 2014; Zasadni and Kłapyta, 2014). There is no evidence of an ice cap covering the highest summits of the massif. The position of glacial trimlines in troughs and cirques clearly limits the maximum extent of active ice below crests (Makos and Nitychoruk, 2011; Makos et al., 2013a). The largest catchments (e.g: BiałaWoda, Koprova) which are usually composed of the main trough and a number of hanging tributary valleys and cirques, were huge glacial basins with glaciers formed as dendritic or at least compound systems. The Biała Woda glacier was the largest system in the High Tatras during the LGM and its area reached over $40 \mathrm{~km}^{2}$. Smaller glaciers, especially on the southern slope of the range were formed as valley glaciers with one accumulation area and one tongue. Morphology of the High Tatra massif and its N-S asymmetry was one of the most significant factor determining the shape and size of glaciers during Pleistocene. The northern glacial troughs are 
much longer and glaciers terminated inside the valleys with normal fronts, while the southern troughs are relatively short, limited only to the range of the crystalline core of the Tatras, and almost all southern glaciers terminated on the foreland of the massif forming expanded fronts (Fig. 2). Very well-formed and preserved moraine ridges and trimlines of the maximum extent give the opportunity for a detail reconstruction of the glacier geometry (Fig. 5). The recent publication of Zasadni and Kłapyta (2014) presents the LGM glacial cover in the Tatras.
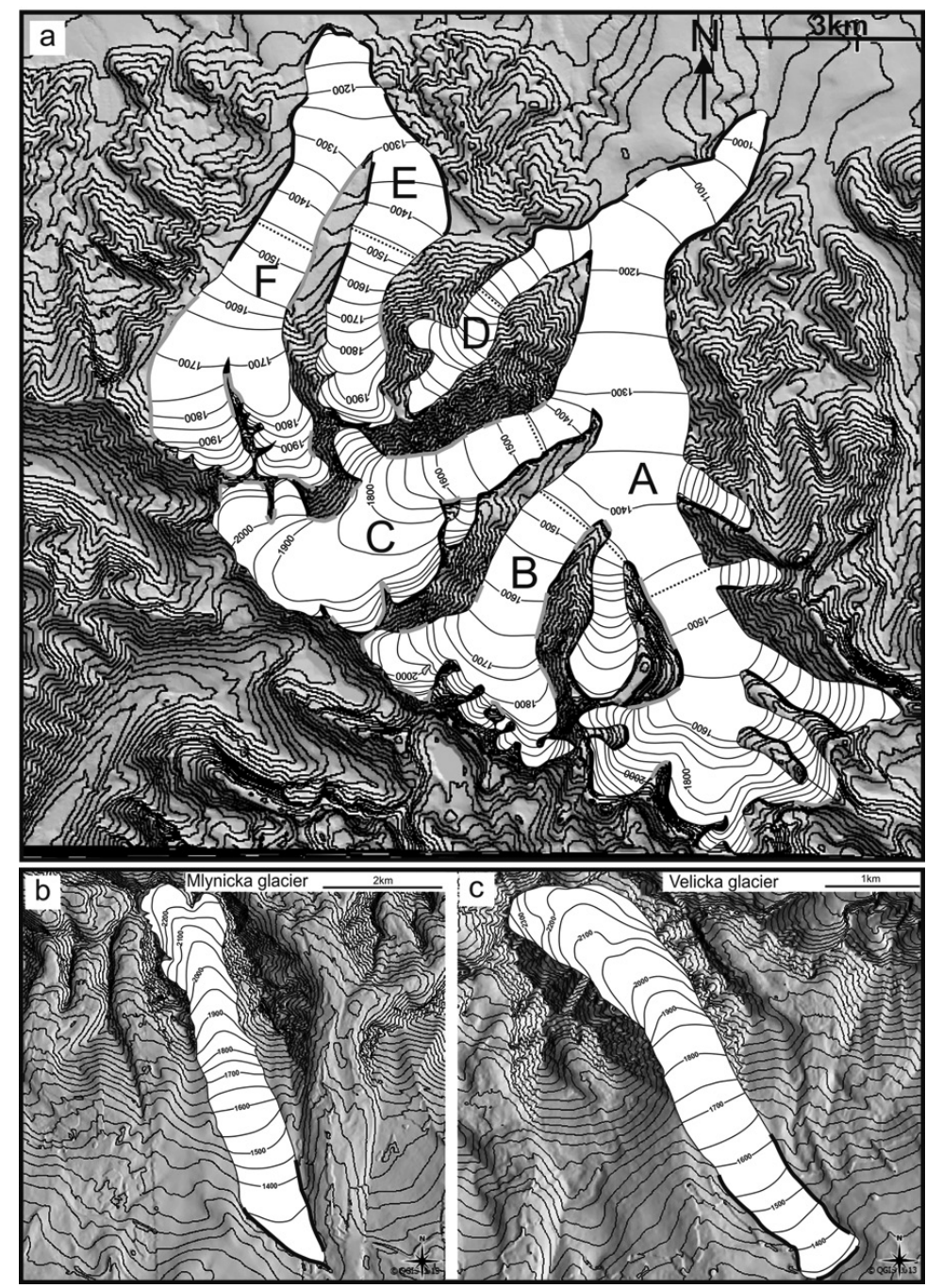

Figure 5. Reconstructed geometry of selected glaciers during the LGM. a) Biała Woda catchment: A - Biała Woda glacier; B - Rybi Potok glacier; C - Roztoka glacier; D - Waksmundzki glacier. Sucha Woda catchment: E - Pańszczyca glacier; F - Sucha Woda glacier; b) Mlynicka glacier; c) Velicka glacier. The contour interval is $50 \mathrm{~m}$. Black, thick, solid lines represent the prominent terminal and lateral moraine ridges. Grey lines represent the glacial trimlines. 
The most prominent, maximum moraine ridges on the northern and southern side of the High Tatra Mountains were a subject of many paleogeographic and geomorphologic studies (e.g: Baumgart-Kotarba and Kotarba, 1997; 2001; Lukniš, 1973). The spatial distribution of glacial accumulation features has been the basis for constructing the morphostratigraphic schemes for few decades (Lukniš, 1973; Lindner, 1994; Lindner et al., 2003; Baumgart-Kotarba and Kotarba, 1997; 2001). The most extended moraine ridges were assumed as formed during the last glacial cycle, probably the LGM. The numerical dating of glacial forms, however, has a very short history in the Tatra Mountains and allowed to review the former conclusions. The glacial chronology in the Tatras is based on the ${ }^{36} \mathrm{Cl}$ exposure age dating methodology so far. Cosmo-datings were applied in the Sucha Woda catchment, the Biała Woda catchment, the Mlynicka Valley and the Velicka Valley (Makos et al. 2013 a; 2014).

The spatial distribution of exposure ages from the terminal moraine system in the Sucha Woda/Pańszczyca catchment suggests at least two stages of moraine formation. There is only one boulder dated on the maximum ridge and its age indicates moraine stabilization around $20.1 \mathrm{ka}$. This age seems reasonable in light of dates obtained from an internal (younger) ridge where most dates are distributed around $18 \mathrm{ka}$ (Fig. 4 and 6). The entire data set can be interpreted as reflecting two periods of glacier stabilization: the older one around $20 \mathrm{ka}$ and the younger one around 18-16.7 ka (Makos et al., 2014).

The maximum extent of the glacier in the Velicka Valley is limited by the well-developed terminal/lateral moraine. Final stabilization of the outer moraine occurred at about 25 ka thus the maximum advance likely took place slightly earlier. The maximum lateral ridge was abandoned by the glacier by about $21.5 \mathrm{ka}$ (Fig. 4 and 6). The significant discrepancy between ages of formation of the lateral and terminal moraines likely reflects the longer preservation of the lateral ridge at the active glacier, while the terminal moraine has already been free of ice. This means that oscillating glacier on the background of the maximum terminal moraine could have been stable at the position of the lateral moraine for at least $3000 \mathrm{yr}$ or that some advance occurred at around 22-23 ka. The mean age of the inner terminal moraine confirms final stabilization of the form by $17.4 \mathrm{ka}$ (Fig. 6) (Makos et al., 2014). This moraine was formed during a re-advance of the glacier or during the temporal stop of deglaciation. The form reflects likely a climatic fluctuation at the end of LGM cold period.

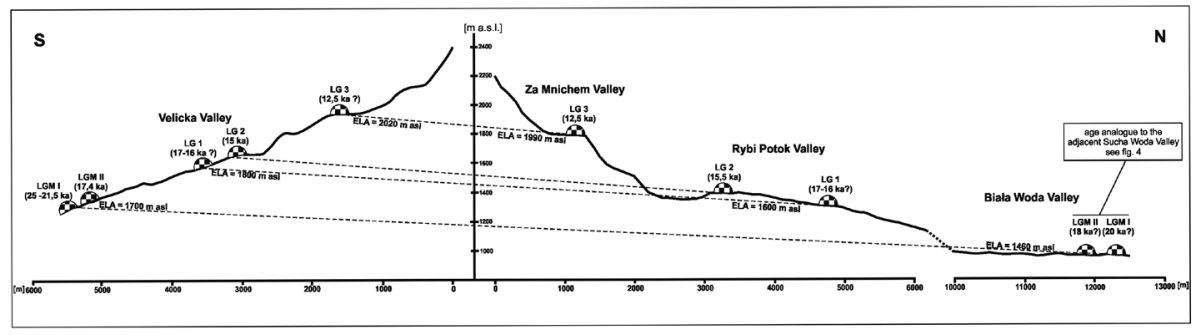

Figure 6. Schematic S-N cross-section through the High Tatra Mountains along the Velicka Valley (southern slope) and Za Mnichem Valley, Rybi Potok Valley and Biała Woda Valley (northern slope). The age of moraine formation is generalized for the whole High Tatra Mountains based on exposure age analysis in the Sucha Woda Valley, Rybi Potok Valley, Roztoka Valley and Velicka Valley (Dzierżek, 2009; Makos et al., 2013 and b; 2014). 
In the lower part of Mlynicka Valley, moraine ridges are a prolongation of the huge moraine system on the foreland of Mengusovska Valley. It was formed by the expanded (nearly piedmont lobe) front of the glacier during at least two stages of glacier activity. The age of boulders indicates that stabilization of the moraine occurred at around 18.7 $\pm 1.2 \mathrm{ka}$ (Fig. 2 and 4) (Makos et al., 2014). This age, however, does not reflect the timing of maximum advance of the Mlynicka/Mengusovska glacier. The moraine was probably stable during the time of glacier oscillation on the foreland of the Mengusovska Valley. Thus similarly to the moraine in the Velicka Valley, the terminal moraine in the Mlynicka Valley evidences the maximum extent of the glacier but not the exact age of the maximum advance.

Stabilization of moraines of the maximum advance on both sides of the massif was not simultaneous (Fig. 4 and 6). The Velicka glacier could have abandoned its maximum position as early as $26 \mathrm{ka}$, whereas the maximum moraine in the Sucha Woda/Panszczyca Valley was finally stabilized a few thousand years later, probably slightly before $21 \mathrm{ka}$. This is partly confirmed by the record from the Pięć Stawów Polskich Valley (Polish High Tatra Mountains) where the first pulse of ice melting occurred at $21.5 \mathrm{ka}$ as inferred from the exposure age of glacially eroded bedrock below the LGM trimline (Makos et al., 2013a). The significant discrepancy between exposure ages of moraines on northern and southern sides of the Tatra Mountains can reflect: (i) a few thousand years earlier advance of the Velicka glacier than the advance of the Sucha Woda/Panszczyca glacier; (ii) simultaneous advance of both glaciers but the final stabilization of moraine in the Sucha Woda Valley occurred a few thousand years later than in the Velicka Valley; (iii) the inheritance of isotope from previous exposition or rejuvenation of the form after its deposition; then obtained dating results do not reflect the true age of glacial activity (Makos et al., 2014). Anyway, the first glacial advance in the High Tatra Mountains during the LGM can be inferred in the time interval between 26 and $21 \mathrm{ka}$. The subsequent stage of glacier activity occurred by the end of LGM at around $18 \mathrm{ka}$ (Fig. 4). This pattern of deglaciation finds confirmation in other mountain ranges in Europe e.g: Rila Mountains (Kuhlemann et al., 2009; 2013). The first pulse of deglaciation in the High Tatra Mountains occurred at about $21.5 \mathrm{ka}$. There are no proxy data from the Tatra Mountains that can confirm the onset of deglaciation of the LGM glaciers. In the European Alps, the deglaciation began around $21.5 \mathrm{ka}$ (Reitner, 2007). Before $18 \mathrm{ka}$, Alpine glaciers lost about $80 \%$ of their volume (Ivy-Ochs et al., 2004, 2006, 2008; Kelly et al., 2006). According to Clark et al. (2009), amelioration of the climatic conditions occurred simultaneously with an increase in northern summer insolation and a rapid rise in sea level about $20 \mathrm{ka}$. According to the GRIP chronology (Lowe et al., 2008), the first LGM advance in the High Tatras occurred during the Greenland Stadial 3 and the subsequent stage of glacier stabilization took place at the Greenland Stadial 2b (Fig. 3 and 4).The paleoclimatic reconstruction based on mass-balance modeling shows that the LGM precipitation distribution over the High Tatra Mountains was different than the present-day one (Fig. 7). By assuming $12^{\circ} \mathrm{C}$ reduced temperature on both the northern and southern slopes, precipitation sums on the northern slope are only $15 \%$ higher than those on the southern one. Temperature reduction of $11^{\circ} \mathrm{C}$ on the southern slope requires slightly higher precipitation there and then distribution of precipitation 
over the High Tatra Mountains seems uniform. Therefore, the difference between LGM ELA (1700 m a.s.l. - south; $1460 \mathrm{~m}$ a.s.l. - north) on both sides of the Tatras is due to either lower precipitation or higher temperature on the southern slope. In both scenarios at least two different patterns of atmospheric circulation could be considered: a uniform participation of the northern and southern advections, especially during the winter, and prevailing western circulation throughout the year. The latter finds confirmation in the slight W-E ELA gradient of the south-facing glaciers.

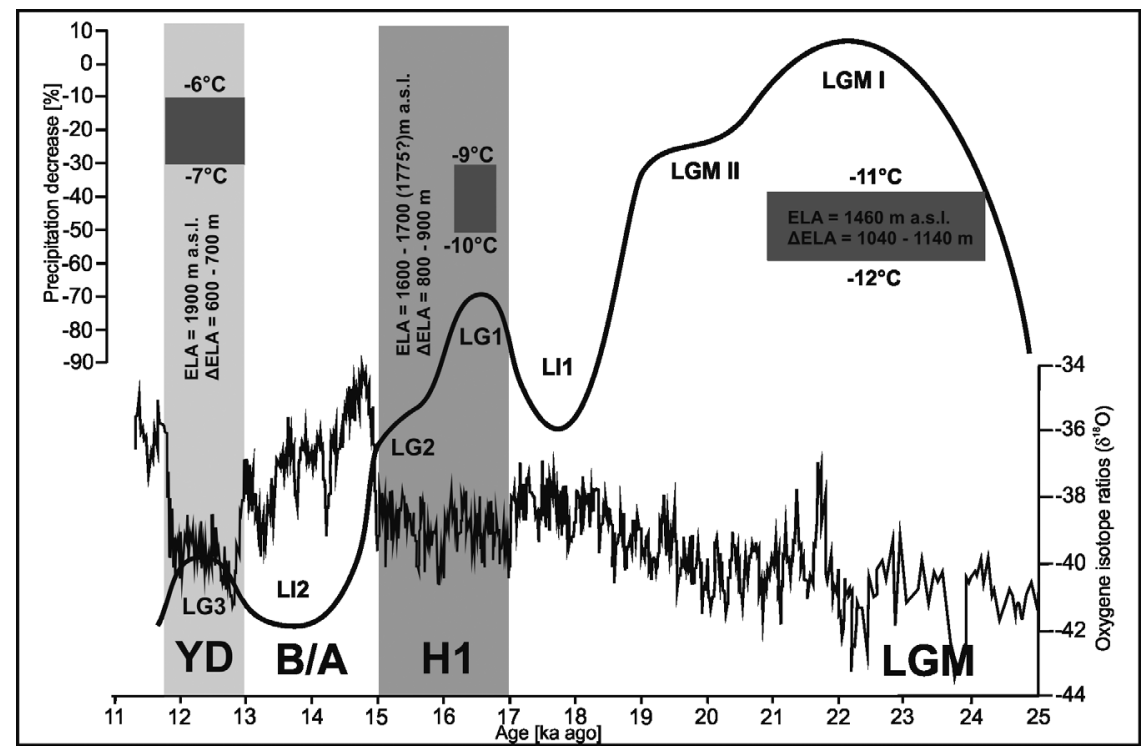

Figure 7. Summary of paleoclimate reconstructions (dark-grey boxes); width: proposed time range of cold episodes based on exposure ages; height: paleoprecipitation reconstructions (Makos et al., $2013 a$ and $b$; 2014) Numbers on top and bottom of the boxes are proposed paleotemperature reconstructions for particular cold periods (LGM I, LG 1 and LG 3). Published time ranges of the H1 event (Hemming, 2004), the Bølling/Allerød and the Younger Dryas (Rasmussen et al., 2006) are indicated. The GRIP ice-core record after (Lowe et al., 2008). Solid black line shows schematic changes of glacier extent during subsequent advances in the study area.

In the light of significantly different sizes of glaciers located on the northern and southern sides of the High Tatra Mountains one might expect that different climatic conditions prevailed on each side (Fig. 5). The results of modeling, however, indicate that conditions on the two sides were probably nearly the same (Makos et al., 2014). This fact confirms that the size of the glacier is constrained not only by climatic parameters but also by the size and shape of the valley. Considering the geometry of glaciers during the LGM, it should be emphasized that they existed in basins that had been glacially eroded throughout the whole Pleistocene. Therefore, the shape and size of valleys are the result of erosion efficiency determined by climatic conditions during several hundred thousand years. According to Křŕžek and Mida (2013) the spatial distribution, shape and size of cirques in the High Tatra Mountains are influenced by moisture sources, which 
were mainly from the NW to N during the cold phases of the Pleistocene. Thus, northfacing cirques have stronger representation and are more incised with steep slopes, and represent highly developed glacial erosion landforms. The south-facing cirques are not so deeply incised and their bottoms are generally located higher than those on the northern slope. During the LGM, glacial erosion had an obvious influence on the morphology of the massif through the rejuvenation of already existing relief. Therefore, the difference of equilibrium-line position and size of glaciers during the LGM in the Tatra Mountains was likely influenced more by geomorphologic conditions than by the spatial diversity of climatic conditions.

\subsection{Lateglacial}

The post-LGM deglaciation of the study area was affected by number of climatic fluctuations during the Lateglacial period. They were firstly recognized based on the geomorphologic evidence, mainly as well-formed moraine ridges located within the range of LGM ice extent, in the upper part of particular catchments. Baumgart-Kotarba and Kotarba (1997) proposed up to ten recessional phases in the Biała Woda catchment, while in the Rybi Potok and Roztoka valleys and SuchaWoda/Pańszczyca catchment there were up to seven recessional phases recognized (Baumgart-Kotarba and Kotarba, 2001). On the southern slope of the massif Lukniš (1973) established five cold stages during the last glacial cycle with the maximum LGM stage (D) and five recessionals during the Lateglacial (D1, D2, E1-E3) (Fig. 3).

The latest research on paleogeography and chronology of deglaciation of the High Tatra Mountains allowed determining the time frames of main cold stages during the Lateglacial. According to exposure ages obtained from the Roztoka and Rybi Potok catchments the first post-LGM glacier advance occurred later than $17.3 \mathrm{ka}$ (Fig. 4). Depending on the scenario, this event took place just before or slightly after 16.9 ka based on exposure age of bedrock below the glacial trimlines (Makos et al., 2013a). Therefore, accumulation of moraines occurred probably within the time range between 17 and $16 \mathrm{ka}$. At that time the lowermost moraines in the Roztoka (1220 m a.s.l.) and Rybi Potok (1300 $\mathrm{m}$ a.s.1.) valleys were formed (Fig. 2). The catchments were already occupied by separate valley glaciers (Fig. 8). According to the morphostratigraphic scheme of Lukniš (1973), the moraines D2 or E1 could be correlated with the cold episode at around 17-16 ka. This is partly confirmed by exposure age of moraine E2 in the Velicka Valley, which is estimated at $15 \mathrm{ka}$ (Makos et al., 2014) (Fig. 4 and 6). The numerically modeled ELA of the Roztoka and Rybi Potok glaciers was located at around $1600 \mathrm{~m}$ a.s.l. during the cold stage at 17-16 ka, however, the AAR (0.6) method suggests even $150 \mathrm{~m}$ higher ELA on the Roztoka glacier (Makos, 2010; Makos et al., 2013a). ELA of southern glaciers was placed at the elevation of $1850 \mathrm{~m}$ a.s.l. on avaerage (Lukniš, 1973) (Fig. 6). Similarly to the LGM, at 17-16 ka the ELA was still inclined form $\mathrm{S}$ to $\mathrm{N}$, reflecting different morphology of the basins and/or different climatic conditions. Climatic parameters for the steady-state glacial conditions on the northern side of the massif indicate mean annual temperature lower by $9-10^{\circ} \mathrm{C}$ and $30-50 \%$ depressed precipitation sum than today (Fig. 7). Thus, the early Lateglacial at 17-16 ka in the High Tatra Mountains was slightly 
wetter and warmer than in Central Alps but much colder and drier than in southern Europe (Makos et al., 2013a; Ivy-Ochs et al., 2006; Sarikaya et al., 2009). The first Lateglacial cold stage coincides well with other chronologies in the mountains of Europe (e.g. Ivy-Ochs et al., 2006, Reuther et al., 2007, Sarikaya et al., 2008) and could have been a reflection of the cold and wet climatic conditions around the North Atlantic during the Greenland Stadial 2b/a (Lowe et al., 2008). This cold period called the Oldest Dryas in the continental Europe is recorded on the foreland of Tatra Mountains in lacustrine deposits and this data set evidences the tundra-like vegetation and thus much colder and drier climate than today (Koperowa, 1962). The first cold stage during the Lateglacial in the High Tatra Mountains will be called the Lateglacial Stadial 1 (LG1) in this study.

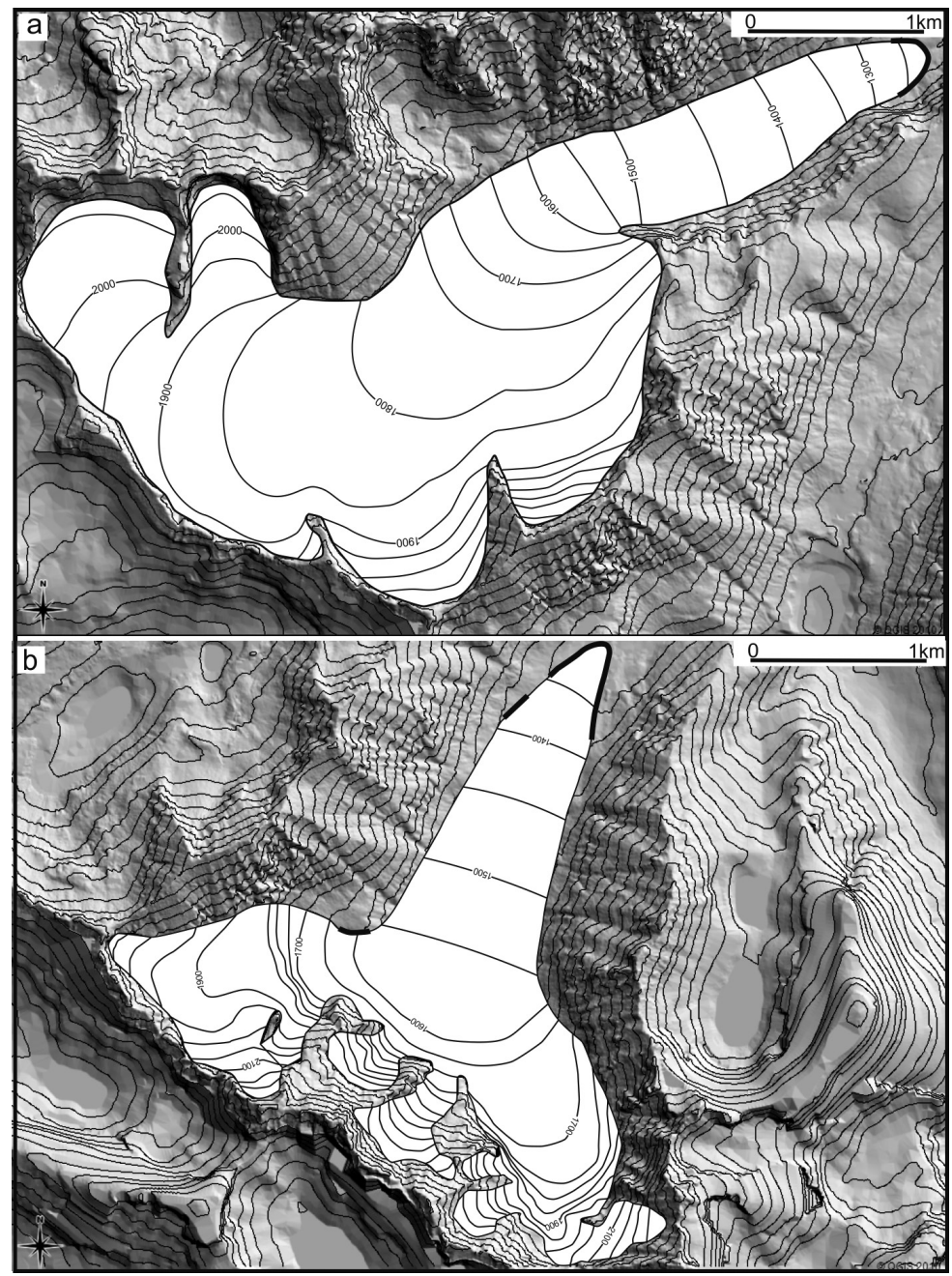

Figure 8. Reconstructed geometry of selected glaciers during the Lateglacial Stadial 1 (LG 1) in: a) Roztoka catchment; b) Rybi Potok catchment. Terminal and lateral moraines are marked by thick, black lines (Makos, 2010; Makos et al., 2013a). 
The subsequent stage of glacier activity in the High Tatra Mountains is recorded as well-formed moraine ridges located further up-valleys from the moraines of LG1 Stadial. On the northern slope of the massif these moraines were defined as R3 and RP4 in the Roztoka catchment and Rybi Potok catchment, respectively (Baumgart-Kotarba and Kotarba, 1997) and SW4 and P4 in the SuchaWoda/Pańszczyca catchment (BaumgartKotarba and Kotarba, 2001). On the southern slope of the Tatras there were moraines of stage E2 accumulated during that cold episode (Lukniš, 1973). Terminal moraine (RP4) located on the foreland of the Morskie Oko Lake in the Rybi Potok Valley gave the exposure age of $15.5 \mathrm{ka}$ (Dzierżek, 2009) (Fig. 4 and 6). Moreover, the sedimentologic record from the Zabie Oko Lake located slightly down the valley from the moraine RP4 indicates that the depression was ice-filled during the cold period when the moraine had been accumulated and the deposition of mineral sediments occurred slightly later, at the beginning of Bølling/Allerød warming. In the Velicka Valley this cold stage is recorded as the E2 moraine in the vicinity of the Velické Lake. Boulders from the moraine gave the exposure age of the form of $15 \mathrm{ka}$ (Makos et al., 2014) (Fig. 4 and 6). In this study the second Lateglacial cold episode will be defined as the Lateglacial Stadial 2 (LG2).

The pollen and sedimentologic analyses form the lakes located in the vicinity of moraines of the LG2 Stadial evidence that they were abandoned by the glaciers at the beginning of the Bølling/Allerød warming called here Lateglacial Intestadial 2 (Krupiński, 1984; Marciniak and Cieśla, 1983, Baumgart-Kotarba and Kotarba, 1995). Moreover, the significant downwasting of glaciers is also recorded by exposure ages of cirque walls in the Pusta Valley and Za Mnichem Valley. There is an evidence of quick thinning of glaciers between 15 and $13.5 \mathrm{ka}$ (Makos et al., $2013 \mathrm{a}$ and b).

At around $13 \mathrm{ka}$ climate in the Tatra Mountains became more severe again. Glaciers, occupying the uppermost areas of the catchments, advanced or were stable and formed large terminal moraines on both northern and southern slope of the massif. The exposure ages from boulders on the threshold of the Za Mnichem Valley show that the moraine was finally stabilized at around $12.5 \mathrm{ka}$ (Makos et al., 2013b) (Fig. 4 and 6). Therefore, according to the chronology of the Lateglacial presented by Björck et al. (1998), this cold episode in the Tatra Mountains can be correlated with the Younger Dryas (Greenland Stadial 1). This cooling is also recorded in the lacustrine sediments of the Żabie Oko Lake as the sequence of fine grained very thin layer of sand reflecting the relatively small outflow from the Morskie Oko Lake. The overlying layer of silts with detritus provide evidence of stable discharges controlled by the lake and the bottom part of organic sediments has been dated to $11.8 \mathrm{cal} \mathrm{ka}\left(9780 \pm 350{ }^{14} \mathrm{C}\right.$ years BP) (BaumgartKotarba and Kotarba, 1995), indicating the onset of Holocene warming. The whole exposure data set from the Za Mnichem Valley clearly shows that the glacier produced the terminal moraine at the valley threshold during the Younger Dryas (Fig. 9). Based on glacier-climate modelling, it is inferred that the glacier was stable when the climate in the valley was colder $\left(4.2-4.6^{\circ} \mathrm{C}\right.$ summer temperature depression; $6^{\circ} \mathrm{C}$ annual temperature depression) and drier (15-25\% annual precipitation depression) than today (Makos et al., 2013b). Such conditions determined lower position of the YD ELA (1990 m a.s.l.) on the northern slope of High Tatras by about $500 \mathrm{~m}$ in relation to the present-day one (Fig. 7). These findings are partly confirmed by a botanical record from the Tatra foreland 
where summer temperature reached around $11.5^{\circ} \mathrm{C}(600 \mathrm{~m}$ a.s.1.) (Koperowa, 1962) and by a timberline depression which was of 400-700 m during the YD (Krupiński, 1984; Obidowicz, 1993). There are very sparse data reflecting the YD paleogeography and climatic conditions in the Slovakian Tatras. According to the study of Lukniš (1973), the moraines E3 could be correlated with cooling of YD but there are no other evidence such a numerical dating of moraines or lacustrine sediments. The ELA of YD glaciers in the 'southern' valleys rose up to $2020 \mathrm{~m}$ a.s.l. The timberline was located at the elevation of around $800 \mathrm{~m}$ a.s.1., and the average summer temperature reached around $11.5-12.5^{\circ} \mathrm{C}$ on the foreland. YD climate in the Slovakian High Tatra Mountains is defined as cold and wet (Lukniš, 1973). In this study the last Lateglacial cold episode will be defined as the Lateglacial Stadial 3 (LG3).

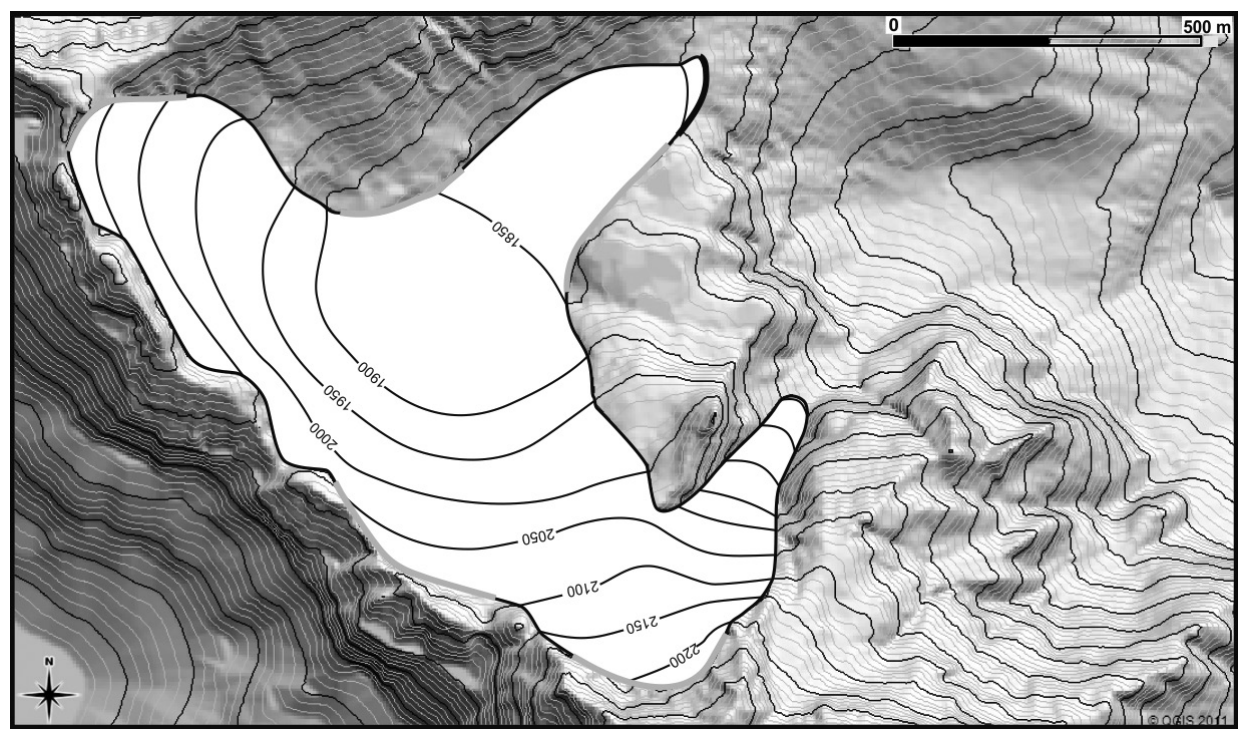

Figure 9. Reconstructed geometry of the Za Mnichem glacier during the Lateglacial Stadial 3 (LG 3). Black, thick lines represent the prominent terminal and lateral moraine ridges. Grey lines represent the glacial trimlines (Makos et al., 2013b).

During the YD cold period mountain glaciers responded markedly across whole Europe. Significant terminal moraines were accumulated e.g.: in the Alps (Kelly et al., 2004, Ivy-Ochs et al., 2009), the Southern Carpathians (Reuther et al., 2007), the Central Carpathians (Rinterknecht et al., 2012), the Pyrenees (Pallàs et al., 2007). Following the timing of the YD moraine stabilization across Europe, it seems that glaciers retreated earlier in the 'eastern' mountains (Rinterknecht et al. 2012) than in the 'western' ones (Pallàs et al. 2007). If the temperature decrease in western and central Europe was uniform, the mass balance of glaciers was determined mostly by precipitation. This suggests a prevailing continentality of climate eastwards during the YD in Europe. 
There is no direct evidence when glaciers finally melted out in the Tatra Mountains. Climatic fluctuations at the beginning of the Holocene are recorded mainly in lacustrine deposits and reflect the environmental changes based on pollen and diatoms analyses as well as radiocarbon dating (e.g: Krupiński, 1984; Marciniak and Cieśla, 1983; BaumgartKotarba and Kotarba, 1995). The onset of sedimentation of organofacies in glacial lakes is dated to about 11.7 ka (Krupiński, 1984; Baumgart-Kotarba and Kotarba, 1995). The pollen assemblages are the basis for reconstruction of the position of timberline. This had been located at $1100 \mathrm{~m}$ a.s.l. during the Pre-boreal, then rose up to 1650 and $1950 \mathrm{~m}$ a.s.1. during the Boreal and Atlantic periods respectively. There is an opinion that the final deglaciation of the Tatra Mountains occurred during the Holocene optimum at around $8.5 \mathrm{ka}$ (Lindner et al., 2003). The exposure age of the polish bedrock on the headwall of the $\mathrm{Za}$ Mnichem cirque indicates that this one was finally exposed by a glacier at about $11 \mathrm{ka}$ (Makos et al., 2013b). However the uppermost, north-faced hanging cirques could have been glaciated slightly longer.

\section{Conclusions}

The current state of knowledge gives the opportunity to create the very general pattern of deglaciation of the High Tatra Mountains, which is based mostly on geomorphologic evidence and a very limited number of exposure datings in few catchments. However, only the comprehensive look at the spatial and temporal diversity of the course of deglaciation in the whole massif will allow comparing the last glacial cycle in the Tatra Mountains with other ranges in Europe. The big advance in the recent paleoclimatic reconstructions across the world is standardization of the methodology. TCN methods are currently widely used and their accuracy is continuously in progress. Glacier-climate models give very promising and comparable results and the studies of mountain climate and ecology have become a major target in Europe, especially for the Mediterranean region (IPCC report, Solomon et al., 2007). It is necessary to extend the range of advanced studies on paleoclimate to central Europe. Thus, further studies using the exposure age dating methodology are necessary to determine the chronology of Pleistocene glacial episodes in all catchments of the Tatra Mountains.

As the northern part of Europe has been affected by the Fennoscandian Ice Sheet during the last glacial cycle, reconstruction of the climate in the Tatra Mountains will help us understanding interactions between the ice sheet and mountain glaciations. It provides a new evidence for atmospheric circulation over Europe during the glacial times, what in consequence is a very useful tool to predict further climatic oscillations depending on changes in air masses movement and moisture inflow in Europe.

\section{Acknowledgements}

The presented research was funded by the grant of the Ministry of Science and Higher Education (Project No. N307 020 32/0544) and by the grant of the National Science Centre (NCN) (Project No. 2011/03/B/ST10/06188). All fieldwork was undertaken with permission of the Tatra National Park. 


\section{References}

Baumgart-Kotarba, M., Kotarba, A. 1995. High Mountain environment of the Tatras in the period of pleistocene and holocene transition. Biuletyn Peryglacjalny 34, 37-51.

Baumgart-Kotarba, M., Kotarba, A. 2002. Deglaciation in the High Tatra Mountains (Biala Woda Valley as example). In Proceedings of XVII CBGA Congress, Bratislava, 1e4 September 2002. Geologica Carpathica, p. 53.

Baumgart-Kotarba, M., Kotarba, A. 1997. Würm glaciation in the BiałaWoda Valley, High Tatra Mountains. Studia Geomorphologica Carpatho-Balcanica 31, 57-81.

Baumgart-Kotarba, M., Kotarba, A. 2001. Deglaciation in the Sucha Woda and Panszczyca valleys in the Polish High Tatras. Studia Geomorphologica Carpatho-Balcanica 35, 7-38.

Björck, S., Walker, M.J.C., Cwynar, L.C., Johnsen, S., Knudsen, K.-L., Lowe, J.J., Wohlfarth, B., INTIMATE Members. 1998. An event stratigraphy for the last Termination in the North Atlantic region based on the Greenland ice-core record: a proposal by the INTIMATE group. Journal of Quaternary Science 13, 283-292.

Butrym, J., Lindner, L., Okszos, D. 1990. Formy rzezby, wiek TL osadów i rozwój lodowców ostatniego zlodowacenia w Dolinie Malej qa ‘ ki, Tatry Zachodnie. Przeglqd Geologiczny 38 (1), $20 \mathrm{e} 26$.

Clark, P.U., Dyke, A.S., Shakun, J.D., Carlson, A.E., Clark, J., Wohlfarth, B., Mitrovica, J.X., Hostetler, S.W., McCabe, M. 2009. The Last Glacial Maximum. Science 325, 710-714.

Dzierżek, J., Nitychoruk, J., Zreda-Gostynska, G., Zreda, M.G. 1999. Metoda datowania kosmogenicznym izotopem $36 \mathrm{Cl}$ e nowe de do chronologii glacjalnej TatrWysokich. Przegląd Geologiczny 11 (47), 987-992.

Dzierżek, J. 2009. Paleogeografia wybranych obszarów Polski w czasie ostatniego zlodowacenia. Acta Geographica Lodziensia 95, 1-112.

Gądek, B. 2008. The problem of firn-ice patchesin the Polish Tatras as an indicator of climatic fluctuations. Geographia Polonica 81 (1), 41-53.

Hemming, S. 2004. Heinrich events:massive Late Pleistocene detritus layers of the North

Atlantic and their global climate imprint. Reviews of Geophysics 42, 1-43.

Ivy-Ochs, S., Kerschner, H., Kubik, P.W., Schlüchter, C. 2006. Glacier response in the European Alps to Heinrich event 1 cooling: the Gschnitz stadial. Journal of Quaternary Science 21, $115 \mathrm{e} 130$.

Ivy-Ochs, S., Kerschner, H., Maisch, M., Christl, M., Kubik, P.W., Schlüchter, C. 2009. Latest Pleistocene and Holocene glacier variation in the European Alps. Quaternary Science Reviews 28, 2137-2149.

Ivy-Ochs, S., Kerschner, H., Reuther, A., Preusser, F., Maisch, M., Kubik, P.W., Schlüchter, C. 2008. Chronology of the last gglacial cycle in the European Alps. Journal of Quaternary Science 23, 559-573.

Ivy-Ochs, S., Schafer, J., Kubik, P.W., Synal, H.-A., Schlüchter, C. 2004. The timing of deglaciation on the northern Alpine foreland (Switzerland). Eclogae Geologicae Helvetiae 97, 47-55.

Kelly, M.A., Kubik, P.W., von Blanckenburg, F., Schlüchter, C. 2006. Surface exposure dating of the Great Aletsch Glacier Egesen moraine system, western Swiss Alps, using the cosmogenic nuclide ${ }^{10}$ Be. Journal of Quaternary Science 19 (5), 431-441.

Kelly, M.A., Ivy-Ochs, S., Kubik, P.W., von Blanckenburg, F., Schlüchter, C. 2006. Exposure ages of glacial erosional features in the Grimsel Passregion, central Swiss Alps. Boreas 35, 634-643.

Klimaszewski, M. 1988. Rzeźba Tatr Polskich. Warszawa.

Koperowa, W. 1962. Póznoglacjalna i holocenska historia roslinnosci Kotliny Nowotarskiej. Acta Paleobotanica 11 (3), 1-62. 
Kř́ržek, M., Mida, P. 2013. The influence of aspect and altitude on the size, shape and spatial distribution of glacial cirques in the High Tatras (Slovakia, Poland). Geomorphology 198, 57-68.

Krupinski, K.M. 1984. Evolution of Late Glacial and Holocene vegetation in the Polish Tatra Mts., based on pollen analysis of sediments of the Przedni StawLake. Bulletin of the Polish Academy of Sciences Earth Sciences 31, 37-48.

Kuhlemann, J., Gachev, E., Gikov, A., Nedkov, S., Krumrei, I., Kubik, P. 2013. Glaciation in the Rila Mountains (Bulgaria) during the Last Glacial Maximum. Quaternary International 293, 51-62.

Kuhlemann, J., Milivojevic, M., Krumrei, I., Kubik, P. 2009. Last glaciation of the Sara Range (Balkan Peninsula): increasing dryness from the LGM to the Holocene. Austrian Journal of Earth Sciences 102, 146-158.

Lindner, L. 1994. Jednostki stadialne i interstadialne ostatniego zlodowacenia (Würm, Vistulian) w Tatrach Polskich i na Podhalu. Acta Geographica Universiti Nicolae Copernici 27, 59-73.

Lindner, L., Dzierżek, J., Marciniak, B., Nitychoruk, J. 2003. Outline of Quaternary glaciations in the Tatra Mountains: their development, age and limits. Geological Quarterly 47 (3), 269-280.

Lowe, J.J., Rasmussen, S.O., Björck, S., Hoek, W.Z., Steffensen, J.P., Walker, M.J.C., Yu, Z.C., The INTIMATE Group. 2008. Synchronisation of palaeoenvironmental events in the North Atlantic region during the Last Termination: a revised protocol recommended by the INTIMATE group. Quaternary Science Reviews 27, 6-17.

Lukniš, M. 1964. The course of Last Glaciation of the Western Carpathians in relation to the Alps, to the glaciation of Northern Europe, and to division of the Central-European Würm into periods. Geografický Casopis 16 (2), 127-142.

Lukniš, M. 1973. Reliéf Vysokých Tatier a ich predpolia. Veda, Bratislava, 375 pp.

Makos, M. 2010. Rekonstrukcja zmian klimatycznych w póznym czwratorzedzie $w$ polskich Tatrach Wysokich na podstawie datowan glacjalnych form erozyjnych. PhD Thesis Arch. Inst. Geol., Warsaw University.

Makos, M., Dzierżek, J., Nitychoruk, J., Zreda, M. 2014. Timing of glacier advances and climate in the High Tatra Mountains (Western Carpathians) during the Last Glacial Maximum. Quaternary Research 82, 1-13.

Makos, M., Nitychoruk, J., Zreda, M. 2013a. Deglaciation chronology and paleoclimate of the Pięciu Stawów Polskich/Roztoki Valley, High Tatra Mountains, Western Carpathians since the Last Glacial Maximum, inferred from $36 \mathrm{Cl}$ exposure dating and glacier-climate modeling. Quaternary International 293, 63-78.

Makos, M., Nitychoruk, J., Zreda, M. 2013b. The Younger Dryas climatic conditions in the Za MnichemValley (Polish High TatraMountains) based on exposure-age dating and glacierclimate modeling. Boreas 42 (3), 745-761.

Makos, M., Nitychoruk, J. 2011. Last GlacialMaximumclimatic conditions in the Polish part of theHigh TatraMountains (Western Carpathians). Geological Quarterly 55, 253-268.

Marciniak, B., Ciesla, A., 1983. Badania diatomologiczne i geochemicznepó znoglacjalnych i holoce nskich osadów z Przedniego Stawu w Dolinie Pie ciu Stawów Polskich (Tatry). Kwartalnik Geologiczny 27 (1), 123-150.

Niedźwiedź, T. 1992. Climate of the Tatra Mountains. Mountain Research and Development 12, 131-146.

Obidowicz, A. 1996. A Late GlacialeHolocene history of the formation of vegetation belts in the Tatra Mts. Acta Paleobotanica 36 (2), 159-206.

Pallàs, R., Rodés, A., Braucher, R., Carcaillet, J., Ortuno, M., Bordonau, J., Bourlès, D., Vilaplana, J.M., Masana, E., Santanach, P. 2007: Late Pleistocene and Holocene glaciation 
in the Pyrenees: a critical review and new evidence from ${ }^{10} \mathrm{Be}$ exposure ages, south-central Pyrenees. Quaternary Science Reviews 25, 2937-2963.

Partsch, J. 1923. Die Hohe Tatra zur Eiszeit. Leipzig.

Patzelt, G. 1975. Unterinntal-Zillertal Pinzgau, Kitzbühel. Spät- und post-glaziale Landschaftsenwicklung. Innsbrucker geographishe Stud. 2, 309-329.

Rasmussen, S.O., Andersen, K.K., Svensson, A., Steffensen, J.P., Vinther, B.M., Clausen, H.B., Siggarrd-Andersen, M.-L., Johnsen, S.J., Larsen, L.B., Dahl-Jensen, P., Bigler, M., Rothlisberger Fisher, K., Goto-Azuma, K., Hansson, M.E., Ruth, U. 2006. A newGreenland ice core chronology for the last glacial termination. Journal of GeophysicalResearch 111, $1-15$.

Reitner, J. 2007. Glacial dynamics at the beginning of Termination 1 in the Eastern Alps and their stratigraphic implications. Quaternary International 164-165, 64-84.

Reuther, A., Urdea, P., Geiger, C., Ivy-Ochs, S., Niller, H.-P., Kubik, P.W., Heine, K., 2007. Late Pleistocene glacial chronology of the Pietrele Valley, Retezat Mountains, Southern Carpathians constrained by ${ }^{10} \mathrm{Be}$ exposure ages and pedological investigations. Quaternary International 164-165, 151-169.

Rinterknecht, V., Matoshko, A., Gorokhowich, Y., Fabel, D., Xu, S. 2012. Expression of the Younger Dryas cold event in the Carpathian Mountains, Ukraine? Quaternary Science Reviews 39, 106-114.

Romer, E. 1929. Tatrzańska epoka lodowa. Prace Geograficzne - Książnica Polska, Lwów, z. 11, $186 \mathrm{~s}$.

Sarikaya, M.A., Zreda, M., Ciner, A. 2009. Glaciations and paleoclimate of Mount Erciyes, central Turkey, since the Last Glacial Maximum, inferred from ${ }^{36} \mathrm{Cl}$ cosmogenic dating central Turkey, since the Last GlacialMaximum, inferred from ${ }^{36} \mathrm{Cl}$ cosmogenic dating and glacier modeling. Quaternary Science Reviews 28, 2326-2341.

Sarikaya, M.A., Zreda, M., Çiner, A., Zweck, C. 2008. Cold and wet Last Glacial Maximum on Mount Sandiras, SW Turkey, inferred from cosmogenic dating and glacier modeling. Quaternary Science Reviews 27, 769-780.

Solomon, S., Qin, D., Manning, M., Alley, R.B., Berntsen, T., Bindoff, N.L., Chen, Z., Chidaisong, A., Gregory, J.M., Hegerl, G.C., Heimann, M., Hewitson, B., Hoskins, B.J., Joos, F., Jouzel, G., Kattsov, V., Lohmann, U., Matsuno, T., Molina, M., Nicholls, N., Overpeck, J., Raga, V., Ramaswamy, J., Ren, J., Rusticucci, M., Somervile, R., Stocker, T.F., Whetton, P., Wood, R.A., Wratt, D. 2007. Technical Summary. In Climate Change 2007: The Physical Science Basis. Contribution of Working Group I tot he Fourth Assessement Report of $t$ he Intergovernmental Panel on Climate Change. Cambridge University Press, Cambridge, $1099 \mathrm{pp}$.

Vitásek, F. 1931. Fysický zempis Tater. Sbírka „Naše Tatry“, Praha, 215 s.

Zasadni J., Kłapyta P. 2014. The Tatra Mountains during the Last Glacial Maximum. Journal of Maps 10 (3), 440-456.

Zasadni, J., K1apyta, P. 2009. An attempt to assess the modern nad Little Ice Age climatic snowline altitude in the Tatra Mountains. Landform Analysis 10, 124-133. 